\title{
HUBUNGAN POLA MAKAN DAN OBESITAS PADA REMAJA DI KOTA BITUNG
}

\author{
${ }^{1}$ Olivia G. Mokolensang \\ ${ }^{2}$ Aaltje E. Manampiring \\ ${ }^{2}$ Fatimawali
}

\author{
${ }^{1}$ Kandidat Skripsi Fakultas Kedokteran Universitas Sam Ratulangi Manado \\ ${ }^{2}$ Bagian Kimia Fakultas Kedokteran Universitas Sam Ratulangi Manado \\ Email: gabbymoko@gmail.com
}

\begin{abstract}
In adolescents, the incidences of overweight and obesity are serious problems because they will continue to develop until the children become mature. Obesity is caused mostly by environmental factors like diet and feeding behavior. The general objective of this research was to determine the correlations between obesity and diet in adolescents from Bitung city. Methods used is descriptive observational analysis with cross sectional design. The results showed that the majority of subjects in this study were women (47\%), and $77.1 \%$ had nutritional status of central obesity, based by waist circumference measurement. From the results of comparative analysis using Fisher exact test, they showed very significant correlation between diet and obesity, for this case is the correlations between intake of energy, carbohydrate, protein and fat with obesity status $(\mathrm{P}<0.01)$. This is confirmed by the results of logistic regression analysis that showed from the intake of various nutrients, fat intake is the most influential variable in the status of obesity from subjects in this study (Exp (B) $=6$, p $<0.01)$. Conclusion: there is a correlation between diet and obesity where the adolescents in this research had excessive diet (all macro-nutrients, like protein, fat and carbohydrate), when seen from the results of nutirent intake analysis compared to the recommended dietary allowance for children teens 13-17 years.
\end{abstract}

Keywords: adolescent, obesity, diet

\begin{abstract}
Abstrak: Pada remaja kejadian kegemukan dan obesitas merupakan masalah yang serius karena akan berlanjut hingga usia dewasa.Obesitas terutama disebabkan oleh pengaruh faktor lingkungan terutama terjadi melalui ketidakseimbangan antara pola makan dan perilaku makan. Tujuan umum dalam penelitian ini adalah untuk mengetahui hubungan pola makan dan obesitas pada remaja di kota bitung. Metode yang digunakan deskriptif observasional analitik menggunakan rancangan cross sectional. Hasil penelitian menunjukkan, sebagian besar subjek penelitian ini adalah perempuan (47\%), dan 77,1\% mempunyai status gizi obesitas sentral berdasarkan hasil pengukuran lingkar pinggang. Dari Hasil analisis komparatif menggunakan fisher exact test menunjukkan secara keseluruhan terdapat hubungan yang sangat bermakna antara pola makan dalam hal ini adalah asupan energi, karbohidrat, protein dan lemak dengan status obesitas $(\mathrm{P}<0,01)$. Hal ini dipertegas pada hasil analisis regresi logistik yang menunjukkan bahwa dari berbagai asupan zat gizi, asupan lemak merupakan variabel yang paling berpengaruh terhadap status obesitas pada subjek dalam penelitian ini $(\operatorname{Exp}(B)=6, p<0,01)$. Simpulan: Adanya hubungan antara pola makan dan obesitas dimana Pola makan anak remaja dalam penelitian ini cenderung lebih (semua zat gizi makro yaitu protein, lemak dan karbohidrat) jika dilihat dari hasil analisis asupan zat gizi dibandingkan dengan angka kecukupan gizi yang dianjurkan pada anak remaja 13-17 tahun.
\end{abstract}

Kata kunci: remaja, obesitas, pola makan 
Obesitas adalah suatu penyakit multifaktorial,yang terjadi akibat akumulasi jaringan lemak berlebihan, obesitas merupakan suatu kelainan kompleks pengaturan nafsu makan dan metabolisme energy yang dikendalikan oleh beberapa faktor biologic spesifik. Secara fisiologis, obesitas didefinisikan sebagai suatu keadaan dengan akumulasi lemak yang tidak normal atau berlebihan di jaringan adipose sehingga dapat mengganggu kesehatan. ${ }^{1}$ Obesitas biasanya dinyatakan dengan adanya $25 \%$ lemak tubuh total pada pria dan sebanyak $35 \%$ atau lebih pada wanita. $^{2}$

Pada anak sekolah, dan remaja kejadian kegemukan dan obesitas merupakan masalah yang serius karena akan berlanjut hingga usia dewasa. Remaja obesitas pada sepanjang hidupnya mempunyai resiko lebih tinggi untuk menderita sejumlah masalah kesehatan yang serius seperti diabetes, penyakit jantung, stroke, dll. Obesitas terutama disebabkan oleh faktor lingkungan. Faktor genetik meskipun diduga juga berperan tetapi tidak dapat menjelaskan terjadinya peningkatan prevalensi kegemukan dan obesitas. Pengaruh faktor lingkungan terutama terjadi melalui ketidakseimbangan antara pola makan dan perilaku makan. Hal ini terutama berkaitan dengan perubahan gaya hidup yang mengarah pada sedentary life style. ${ }^{3}$

Di Indonesia, terutama di kota-kota besar, dengan adanya perubahan gaya hidup yang menjurus ke westernisasi dan sedentary berakibat pada perubahan polamakan / konsumsi masyarakat yang merujuk pada polamakan tinggi kalori , tinggi lemak dan kolesterol, $^{4,5}$ terutama terhadap penawaran makanan siap saji ( fastfood) yang berdampak meningkatkan risiko obesitas. $^{4}$

Prevalensi overweight dan obesitas pada anak di dunia meningkat dari 4,2\% di tahun 1990 menjadi 6,7\% di tahun 2010, dan diperkirakan akan mencapai 9,1\% di tahun 2020. ${ }^{6}$ Berdasarkan data Riset Kesehatan Dasar (Riskesdas) 2013, didapatkan prevalensi obesitas pada anak berusia 5-12 tahun adalah 8,8\%, 13-15 tahun adalah 2,5\%, dan 16-18 tahun adalah $1,6 \%$ berdasarkan indeks massa tubuh menurut umur lebih dari $\mathrm{Z}$ score2 menggunakan baku antropometri WHO 2007 untuk anak berumur 5-18 tahun. ${ }^{6}$

\section{METODE PENELITIAN}

Jenis penelitian ini deskriptif observasional analitik menggunakan rancangan cross sectional penelitian ini mendeskripsikan bagaimana hubungan antara pola makan dengan terjadinya obesitas yang ditunjukkan dengan kekuatan hubungan rasio prevalensi.

Penelitian ini dilaksanakan di wilayah Kota Bitung khususnya pada SMA Negeri 1 dan SMA Negeri 2 Bitung. Populasi dalam penelitian ini adalah seluruh siswa SMA negeri 1 dan SMA Negeri 2 Bitung mulai kelas X hingga kelas XII. Subjek dalam penelitian ini ditentukan berdasarkan kriteria inklusi. Besar sampel dalam penelitian ini dihitung berdasarkan rumus perhitungan besar sampel estimating the diference between two population proportion sebesar 83 siswa. Teknik penentuan sampel dalam penelitian ini dilakukan secara sistematik sampling dimana jumlah populasi dibagi dengan jumlah sampel dan hasilnya merupakan angka kelipatan setiap sampel. Kriteria inklusi dari penelitian ini adalah Siswa dan siswi SMA di Kota Bitung, sehat, dan terdaftar aktif sekolah dengan Kriteria eksklusi yaitu Siswa dan siswi SMA Kota Bitung yang tidak bersedia dijadikan sampel penelitian, Tidak berada ditempat saat pelaksanaan penelitian, Tidak mengikuti semua rangkaian pengambilan data dan Tidak menandatangani persetujuan penelitian. Instrumen penelitian yaitu Pita pengukur lingkar pinggang, timbangan digital, microtoice, alat tulis menulis, Instrumen Penelitian Data umum untuk karakteristik responden menggunakan kuesioner identitas (Nama, umur, jenis kelamin), Frekuensi konsumsi makanan atau FFQ (Food Frequency Questionaire), food recal 24 jam, Sumber makanan Karbohidrat, Lemak, Protein 
dihitung konsumsi zat gizinya menggunakan program software Nutri Survei jumlah asupan energi yang dikonsumsi sehari selanjutnya dibandingkan dengan AKG (Angka Kecukupan Gizi). Analisis data menggunakan program spss 16,0 for windows dimulai editing, coding kemudian entry setelah itu dilanjutkan dengan analisis univariat karakteristik dan distribusi frekuensi kemudian dilanjutkan dengan analisis bivariat dalam hal ini adalah analisis komparative fisher exact test dan dilanjutkan dengan analisis multivariate menggunakan metode backward Logistic regresion. Hasil analisis kemudian disajikan dalam bentuk tabel.

\section{HASIL PENELITIAN}

Subjek dalam penelitian ini pada umumnya berasal dari SMA Negeri 1 dan SMA Negeri 2 Kota Bitung. Kedua sekolah ini dipilih secara consecutif oleh karena berbagai pertimbangan peneliti antara lain mempunyai jumlah siswa yang banyak, banyaknya penjualan makanan yang ada disekitar sekolah, dan mudah dijangkau.

\section{Analisis Univariat}

Karakteristik variabel dalam penelitian ini meliputi jenis umur, hasil pengukuran lingkar pinggang, hasil berat badan, tinggi badan, indeks masa tubuh dan asupan zat gizi selengkapnya dapat dilihat pata tabel berikut ini :

Tabel 1. Karakteristik variable siswa dan siswi SMA 1 dan SMA 2 bitung

\begin{tabular}{ccccc}
\hline Variabel & Mean \pm SD & Min & Maks & $\mathrm{p}^{*}$ \\
\hline Umur (thn) & $15,01 \pm 0,57$ & 14 & 17 & 0,000 \\
Berat Badan (kg) & $59,92 \pm 1,53$ & 37 & 103 & 0,009 \\
Tinggi Badan (cm) & $159,22 \pm 7,27$ & 145 & 176 & 0,200 \\
Lingkar Pinggang (cm) & $86,01 \pm 8,81$ & 69 & 115 & 0,011 \\
Indeks MasaTubuh & $23,20 \pm 5,62$ & 14 & 38 & 0,020 \\
Asupan Energi (Kal) & $2727 \pm 5,65$ & 1598 & 4472 & 0,000 \\
Asupan Karbohidrat (gr) & $414,19 \pm 1,36$ & 186 & 847 & 0,000 \\
Asupan protein (gr) & $99,25 \pm 2,92$ & 42 & 172 & 0,000 \\
Asupan Lemak (gr) & $94,74 \pm 1,93$ & 74 & 150 & 0,000 \\
Persen Asupan Energi (\%) & $116,64 \pm 2,67$ & 73 & 196 & 0,056 \\
Persen Asupan Karbohidrat (\%) & $128,02 \pm 4,46$ & 63 & 267 & 0,002 \\
Persen Asupan Protein (\%) & $147,46 \pm 5,39$ & 72 & 291 & 0,001 \\
Persen Asupan Lemak & $117,46 \pm 2,72$ & 81 & 182 & 0,000 \\
\hline
\end{tabular}

p* Analisis Kolmogorof Smirnof (melihat sebaran data)

Keterangan :

$\begin{array}{ll}\text { mean } & =\text { rata-rata hasil data } \\ \mathrm{SD} & =\text { standart deviasi } \\ \text { Min } & =\text { minimal } \\ \text { Maks } & =\text { maksimal }\end{array}$

\section{BAHASAN}

Hasil analisis karakteristik subjek dalam penelitian ini menunjukkan bahwa Subjek dalam penelitian ini mempunyai rata-rata umur 15 tahun umur terendah 14 tahun dan tertinggi 17 tahun. Jika dilihat dari penilaian pengukuran lingkar pinggang maka dapat dikatakan bahwa subjek dalam penelitian ini sebagian besar mempunyai kecenderungan terjadinya obesitas sentral ditandai dengan hasil pengukuran lingkar pinggang reratanya adalah $86 \mathrm{~cm}$ oleh karena sebagian besar subjek dalam penelitian ini adalah perempuan (47\%). Jika dilihat dari rerata asupan dan persen asupan hasil recall konsumsi dibandingkan dengan standar angka kecukupan gizi yang dianjurkan (AKG 2013) menunjukkan 
bahwa secara keseluruhan subjek dalam penelitian ini mempunyai asupan zat gizi makro diatas angka kecukupan gizi yang dianjurkan (>110\%).

Hasil penelitian ini menunjukkan bahwa sebagian besar subjek dalam penelitian ini adalah perempuan (47\%), dan $77,1 \%$ diantaranya mempunyai status gizi obesitas sentral berdasarkan hasil pengukuran lingkar pinggang, jika dilihat dari indeks masa tubuh subjek dalam penelitian ini 50\% diantaranya tergolong obesitas dan overweight. Jika dilihat dari persentase asupan zat gizi baik energi, karbohidrat, protein dan lemak subjek dalam penelitian ini pada umumnya menunjukkan persen asupan yang berlebihan antara 40-50\% diatas kecukupan yang dianjurkan walupun masih ada subjek yang mempunyai asupan kurang dari angka kecukuapan yang dianjurkan sebesar 19$25 \%$.
Dalam penelitian ini dilakukan eksplorasi terkait frekuensi makan subjek menggunakan formulir food frekuensi menunjukkan bahwa subjek mengkonsumsi makanan sumber karbohidrat cenderung lebih sering adalah nasi, mie, kentang goreng sedangkan sumber protein lebih cenderung telur ayam, daging ayam dan hasil olahannya antara lain sosis dan nugget, tahu dan tempe. Frekuensi makan sayur pada subjek dalam penelitian ini lebih banyak pada sayur kangkung, kol, bayam dan timun sedangkan jenis buah yang sering dikonsumsi pada subjek dalam penelitian ini adalah pepaya mangga dan pisang, jika dilihat dari hasil kuesioner FFQ menunjukkan bahwa makanan jajanan seperti ice cream, bakso, batagor, roti, minuman berkarbonasi, dan pop ice merupakan kegemaran subjek dalam penelitian ini bahkan frekuensinya bisa mencapai 4-7 kali sehari. Analisis Komparatif (Fisher Exact Test).

Tabel 2. Distribusi frekuensi variable SMA 1 dan SMA 2 bitung

\begin{tabular}{cccc}
\hline Variabel & Kategori & N & $\%$ \\
\hline \multirow{3}{*}{ Jenis Kelamin } & Laki-laki & 36 & 43,4 \\
& Perempuan & 47 & 56,6 \\
& Total & 83 & 100 \\
\hline \multirow{3}{*}{ Lingkar Perut } & Obesitas Sentral & 64 & 77,1 \\
& Normal & 19 & 22,9 \\
& Total & 83 & 100 \\
\hline & Obesitas & 35 & 42,2 \\
Indeks Masa Tubuh & Overweight & 4 & 4,8 \\
& Normal & 38 & 45,8 \\
& Kurang & 6 & 7,2 \\
& Total & 83 & 100 \\
\hline \multirow{3}{*}{ Asupan Karbohidrat } & Kurang & 20 & 24,1 \\
Berdasarkan AKG & Cukup & 15 & 18,1 \\
& Lebih & 48 & 57,8 \\
& Total & 83 & 100 \\
\hline \multirow{2}{*}{ Asupan Protein } & Kurang & 25 & 30,1 \\
Berdasarkan AKG & Cukup & 7 & 8,4 \\
& Lebih & 51 & 61,4 \\
& Total & 83 & 100 \\
\hline \multirow{2}{*}{ Asupan Lemak } & Kurang & 19 & 22,9 \\
Berdasarkan AKG & Cukup & 20 & 24,1 \\
& Lebih & 44 & 53,0 \\
& Total & 83 & 100 \\
\hline
\end{tabular}

Keterangan : $\mathrm{N}=$ Jumlah responden 
Analisis Bivariat

Berikut ini ialah hasil analisis komparatif antara asupan energi, karbohidrat, protein dan lemak dengan hasil pengukuran lingkar pinggang (gambaran obesitas sentral) (Tabel 3).

Tabel 3. Hasil analisis komperatif fisher exact test berdasarkan lingkar pinggang untuk menilai asupan energi,karbohidrat, protein dan lemak

\begin{tabular}{ccccccc}
\hline \multirow{2}{*}{ Variabel } & \multirow{2}{*}{ Kategori } & \multicolumn{2}{c}{ Obesitas } & \multirow{2}{*}{ Normal } & \multirow{2}{*}{$\mathrm{P}$} \\
\cline { 3 - 6 } & & $\mathrm{N}$ & $\%$ & $\mathrm{~N}$ & $\%$ & \\
\hline \multirow{2}{*}{ Asupan Energi } & Kurang & 3 & 15,8 & 16 & 84,2 & \\
Berdasarkan & Cukup & 16 & 94,1 & 1 & 5,9 & \multirow{2}{*}{0,000} \\
AKG & Lebih & 45 & 95,7 & 2 & 4,3 & \\
& & 64 & 77,1 & 19 & 22,9 & \\
\hline \multirow{2}{*}{ Asupan KH } & Kurang & 4 & 20 & 16 & 80 & \\
Berdasarkan & Cukup & 12 & 80 & 3 & 20 & \multirow{2}{*}{0,000} \\
AKG & Lebih & 48 & 100 & 0 & 100 & \\
& & 64 & 77,1 & 19 & 22,9 & \\
Asupan Protein & Kurang & 7 & 28 & 18 & 72 & \\
Berdasarkan & Cukup & 7 & 100 & 0 & 0 & \multirow{2}{*}{0,000} \\
AKG & Lebih & 50 & 98 & 1 & 2 & \\
& & 64 & 77,1 & 19 & 22 & \\
\hline \multirow{2}{*}{ Asupan Lemak } & Kurang & 3 & 15,8 & 16 & 84,2 & \\
Berdasarkan & Cukup & 18 & 90 & 2 & 10 & \multirow{2}{*}{0,000} \\
AKG & Lebih & 43 & 97,7 & 1 & 2,3 & \\
& & 64 & 77,1 & 19 & 23,9 & \\
\hline
\end{tabular}

Keterangan :

Nilai kemaknaan $\mathrm{P}<0,001$ (Fisher Exact Test)

$\mathrm{N} \quad=$ Jumlah responden

Hasil analisis komparatif menggunakan fisher exact test menunjukkan secara keseluruhan terdapat hubungan yang sangat bermakna antara pola makan dalam hal ini adalah asupan energi, karbohidrat, protein dan lemak dengan status obesitas $(\mathrm{P}<0,01)$ dengan kata lain pola makan yang dieksplorasi dalam penelitian ini dapat dikatakan sebagai salah satu faktor risiko terjadinya obesitas pada subjek dalam penelitian ini. Hal ini dipertegas pada hasil analisis regresi logistik yang menunjukkan bahwa dari berbagai asupan zat gizi, asupan lemak merupakan variabel yang paling berpengaruh terhadap status obesitas pada subjek dalam penelitian ini pola makan dalam hal ini adalah asupan energi, karbohidrat, protein dan lemak $(\operatorname{Exp}(B)=6$, $\mathrm{p}<0,01$ ).

Penelitian di Amerika dan Finlandia menunjukkan bahwa kelompok dengan asupan tinggi lemak mempunyai risiko peningkatan berat badan lebih besar dibanding kelompok dengan asupan rendah lemak dengan OR 1,7. Penelitian lain menunjukkan peningkatan konsumsi daging akan meningkatkan risiko obesitas sebesar 1,46 kali. ${ }^{7}$ Keadaan ini disebabkan oleh karena makanan berlemak mempunyai energi density lebih besar dan lebih tidak mengenyangkan serta mempunyai efek termogenesis yang lebih kecil dibandingkan dengan makanan yang banyak mengandung protein dan karbohidrat. Makanan berlemak juga mempunyai rasa yang sangat lezat sehingga akan meningkatkan selera makan yang pada akhirnya menyebabkan trjadinya konsumsi yang berlebihan. ${ }^{8}$ 
Analisis Multivariat

Analisis multivariat dalam penelitian ini untuk menjelaskan dari sejumlah faktor risiko terjadinya obesitas dalam hal ini adalah asupan energi, karbohidrat, protein dan lemak mana yang paling berpengaruh atau yang paling berisiko menyebabkan obesitas. Berikut ini ialah analisis regresi logistik menggunakan metode backward Logistic regresion selengkapnya dapat dilihat pada Tabel 4.

Tabel 4. Analisis regresi logistik menggunakan metode backward logistic regresion untuk mencari faktor risiko asupan yang paling berpengaruh pada obesitas

\begin{tabular}{|c|c|c|c|c|c|c|c|c|c|}
\hline \multicolumn{10}{|c|}{ Variables in the Equation } \\
\hline & & \multirow{2}{*}{ B } & \multirow{2}{*}{ S.E. } & \multirow{2}{*}{ Wald } & \multirow{2}{*}{ Df } & \multirow{2}{*}{ Sig. } & \multirow{2}{*}{$\operatorname{Exp}(B)$} & \multicolumn{2}{|c|}{$\begin{array}{c}\text { 95,0\% C.I.for } \\
\text { EXP(B) }\end{array}$} \\
\hline & & & & & & & & Lower & Upper \\
\hline \multirow[t]{13}{*}{ Step $1^{\mathrm{a}}$} & trans_persene & & & .000 & 2 & 1.000 & & & \\
\hline & trans_persene(1) & -16.221 & 3.330E3 & .000 & 1 & .996 & .000 & .000 & . \\
\hline & trans_persene(2) & 31.641 & 3.392E3 & .000 & 1 & .993 & 5.515E13 & .000 & . \\
\hline & trans_persenkh & & & .000 & 2 & 1.000 & & & \\
\hline & trans_persenkh(1) & 99.246 & 7.826E3 & .000 & 1 & .990 & $1.265 \mathrm{E} 43$ & .000 & . \\
\hline & trans_persenkh(2) & 131.190 & $1.015 \mathrm{E} 4$ & .000 & 1 & .990 & $9.443 E 56$ & .000 & . \\
\hline & trans_persenp & & & .000 & 2 & 1.000 & & & \\
\hline & trans_persenp(1) & -15.561 & 2.394E3 & .000 & 1 & .995 & .000 & .000 & . \\
\hline & trans_persenp(2) & -33.365 & 7.728E3 & .000 & 1 & .997 & .000 & .000 & . \\
\hline & trans_persenlmk & & & .000 & 2 & 1.000 & & & \\
\hline & trans_persenlmk(1) & 100.003 & 8.069E3 & .000 & 1 & .990 & 2.696E43 & .000 & . \\
\hline & trans_persenlmk(2) & 32.740 & 3.392E3 & .000 & 1 & .992 & 1.655E14 & .000 & . \\
\hline & Constant & $\begin{array}{c}- \\
148.369 \\
\end{array}$ & $1.097 \mathrm{E} 4$ & .000 & 1 & .989 & .000 & & \\
\hline \multirow[t]{10}{*}{ Step $2^{\mathrm{a}}$} & trans_persene & & & .000 & 2 & 1.000 & & & \\
\hline & trans_persene(1) & -16.502 & 3.832E3 & .000 & 1 & .997 & .000 & .000 & . \\
\hline & trans_persene(2) & 16.396 & $2.814 \mathrm{E} 3$ & .000 & 1 & .995 & $1.320 \mathrm{E} 7$ & .000 & . \\
\hline & trans_persenkh & & & .000 & 2 & 1.000 & & & \\
\hline & trans_persenkh(1) & 69.271 & 7.112E3 & .000 & 1 & .992 & $1.213 \mathrm{E} 30$ & .000 & . \\
\hline & trans_persenkh(2) & 86.402 & $8.021 \mathrm{E} 3$ & .000 & 1 & .991 & 3.340E37 & .000 & . \\
\hline & trans_persenlmk & & & .000 & 2 & 1.000 & & & \\
\hline & trans_persenlmk(1) & 70.341 & 7.084E3 & .000 & 1 & .992 & 3.538E30 & .000 & . \\
\hline & trans_persenlmk(2) & 17.494 & 2.814E3 & .000 & 1 & .995 & 3.959E7 & .000 & . \\
\hline & Constant & $\begin{array}{c}- \\
103.896 \\
\end{array}$ & $9.386 \mathrm{E} 3$ & .000 & 1 & .991 & .000 & & \\
\hline \multirow[t]{6}{*}{ Step $3^{\mathrm{a}}$} & trans_persenkh & & & .000 & 2 & 1.000 & & & \\
\hline & trans_persenkh(1) & 37.260 & 5.977E3 & .000 & 1 & .995 & $1.520 \mathrm{E} 16$ & .000 & . \\
\hline & trans_persenkh(2) & 54.424 & 7.350E3 & .000 & 1 & .994 & 4.326E23 & .000 & . \\
\hline & trans_persenlmk & & & 1.651 & 2 & .438 & & & \\
\hline & trans_persenlmk(1) & 38.742 & 5.884E3 & .000 & 1 & .995 & 6.691E16 & .000 & . \\
\hline & trans_persenlmk(2) & 1.792 & 1.394 & 1.651 & 1 & 199 & 6.000 & 390 & 92.277 \\
\hline
\end{tabular}




\begin{tabular}{|c|c|c|c|c|c|c|c|c|c|}
\hline \multicolumn{10}{|c|}{ Variables in the Equation } \\
\hline & & \multirow[t]{2}{*}{ B } & \multirow{2}{*}{ S.E. } & \multirow{2}{*}{ Wald } & \multirow{2}{*}{ Df } & \multirow{2}{*}{ Sig. } & \multirow{2}{*}{$\operatorname{Exp}(B)$} & \multicolumn{2}{|c|}{$\begin{array}{c}\text { 95,0\% C.I.for } \\
\text { EXP(B) }\end{array}$} \\
\hline & & & & & & & & Lower & Upper \\
\hline \multirow[t]{13}{*}{ Step $1^{\mathrm{a}}$} & trans_persene & & & .000 & 2 & 1.000 & & & \\
\hline & trans_persene(1) & -16.221 & 3.330E3 & .000 & 1 & .996 & .000 & .000 & . \\
\hline & trans_persene(2) & 31.641 & 3.392E3 & .000 & 1 & .993 & $5.515 \mathrm{E} 13$ & .000 & . \\
\hline & trans_persenkh & & & .000 & 2 & 1.000 & & & \\
\hline & trans_persenkh(1) & 99.246 & 7.826E3 & .000 & 1 & .990 & $1.265 \mathrm{E} 43$ & .000 & . \\
\hline & trans_persenkh(2) & 131.190 & $1.015 \mathrm{E} 4$ & .000 & 1 & .990 & 9.443E56 & .000 & . \\
\hline & trans_persenp & & & .000 & 2 & 1.000 & & & \\
\hline & trans_persenp(1) & -15.561 & 2.394E3 & .000 & 1 & .995 & .000 & .000 & . \\
\hline & trans_persenp(2) & -33.365 & 7.728E3 & .000 & 1 & .997 & .000 & .000 & . \\
\hline & trans_persenlmk & & & .000 & 2 & 1.000 & & & \\
\hline & trans_persenlmk(1) & 100.003 & 8.069E3 & .000 & 1 & .990 & 2.696E43 & .000 & . \\
\hline & trans_persenlmk(2) & 32.740 & 3.392E3 & .000 & 1 & .992 & $1.655 \mathrm{E} 14$ & .000 & . \\
\hline & Constant & $\begin{array}{c}- \\
148.369\end{array}$ & 1.097E4 & .000 & 1 & .989 & .000 & & \\
\hline \multirow[t]{10}{*}{ Step $2^{\mathrm{a}}$} & trans_persene & & & .000 & 2 & 1.000 & & & \\
\hline & trans_persene(1) & -16.502 & 3.832E3 & .000 & 1 & .997 & .000 & .000 & . \\
\hline & trans_persene(2) & 16.396 & $2.814 \mathrm{E} 3$ & .000 & 1 & .995 & $1.320 \mathrm{E} 7$ & .000 & . \\
\hline & trans_persenkh & & & .000 & 2 & 1.000 & & & \\
\hline & trans_persenkh(1) & 69.271 & 7.112E3 & .000 & 1 & .992 & $1.213 \mathrm{E} 30$ & .000 & . \\
\hline & trans_persenkh(2) & 86.402 & 8.021E3 & .000 & 1 & .991 & 3.340E37 & .000 & . \\
\hline & trans_persenlmk & & & .000 & 2 & 1.000 & & & \\
\hline & trans_persenlmk(1) & 70.341 & 7.084E3 & .000 & 1 & .992 & 3.538E30 & .000 & . \\
\hline & trans_persenlmk(2) & 17.494 & $2.814 \mathrm{E} 3$ & .000 & 1 & .995 & 3.959E7 & .000 & . \\
\hline & Constant & $\begin{array}{c}- \\
103.896 \\
\end{array}$ & $9.386 \mathrm{E} 3$ & .000 & 1 & .991 & .000 & & \\
\hline \multirow[t]{7}{*}{ Step $3^{\mathrm{a}}$} & trans_persenkh & & & .000 & 2 & 1.000 & & & \\
\hline & trans_persenkh(1) & 37.260 & 5.977E3 & .000 & 1 & .995 & $1.520 \mathrm{E} 16$ & .000 & . \\
\hline & trans_persenkh(2) & 54.424 & 7.350E3 & .000 & 1 & .994 & 4.326E23 & .000 & . \\
\hline & trans_persenlmk & & & 1.651 & 2 & .438 & & & \\
\hline & trans_persenlmk(1) & 38.742 & $5.884 \mathrm{E} 3$ & .000 & 1 & .995 & 6.691E16 & .000 & $\cdot$ \\
\hline & trans_persenlmk(2) & 1.792 & 1.394 & 1.651 & 1 & .199 & 6.000 & .390 & 92.277 \\
\hline & Constant & -56.621 & 7.350E3 & .000 & 1 & .994 & .000 & & \\
\hline
\end{tabular}

a. Variable(s) entered on step 1: trans_persene, trans_persenkh, trans_persenp, trans_persenlmk.

\section{SARAN}

1. Penelitian ini dapat memberikan informasi pada instansi terkait dalam upaya pengendalian faktor risiko terjadinya obesitas pada anak remaja salah satunya adalah pola makan yang melebihi angka kecukupan gizi yang dianjurkan

2. Asupan zat gizi makro dalam hal ini lemak dan karbohidrat merupakan zat gizi yang dalam penelitian ini memberikan kontribusi positif terhadap 
status obesitas pada remaja sehingga perlu kepedulian keluarga dan pihak sekolah untuk memilih dan menyajikan menu makanan yang sehat tinggi serat dan rendah lemak.

3. Perlu perhatian khusus terhadap fenomenan peningkatan prevalensi obesitas pada anak remaja khsususnya di Kota Bitung.

4. Penelitian ini dapat dilanjtukan menggunakan sampel yang lebih besar dan mewakili semua wilayah di Kota Bitung.

\section{DAFTAR PUSTAKA}

1. Sudoyo AW, Setiyohadi B, Alwi I, Simadibrata M, Setiati S. Buku Ajar Ilmu Penyakit Dalam Jilid II edisi VI. Jakarta: Interna Publishing; 2014. p. 2563.

2. Guyton AC, Hall JE. (2008). Buku ajarFisiologi kedokteran Ed. 11. Jakarta: EGC. p. 889, 917-8.

3. Anonim. Pedoman pencegahan dan penanggulangan kegemukan dan obesitas pada anak sekolah. Kementrian kesehatan RI. Jakarta : Kementerian Kesehatan RI. 2011. p. 5-7.

4. Satoto, Karjati S, Darmojo B, Tjokroprawiro A, Kodyat BA. Kegemukan, obesitas dan penyakit degeneratif: epidemiologi dan strategi penanggulangannya, dalam: widyakarya nasional pangan dan gizi VI tahun 1998. Jakarta: LIPI, p. 87 90.

5. Heird WC. Parental Feeding Behavior and Children's Fat Mass. Am J Clin Nutr, 2002; 75: $451-452$

6. Anonim. Riset Kesehatan Dasar 2013. Badan Penelitian dan Pengembangan Kesehatan. Kementerian Kesehatan RI Tahun 2013. p. 203-4

7. Fukuda S, Takeshita T, Morimoto $K$. Obesity and Lifestyle. Asian Med.J., 2001; 44: 97-102.

8. Kopelman GD. Obesity as a medical problem, NATURE, 2000; 404: 63543. 